\title{
RĘKOPIS WIZYTACJI DIECEZJI KAMIENIECKIEJ Z 1777 ROKU Z ARCHIWUM KRAKOWSKIEJ KAPITULY KATEDRALNEJ NA WAWELU
}

W Archiwum Kapitulnym na Wawelu przechowywany jest rękopis opatrzony tytułem „Acta visitationis generalis Dioecesis Camenecensis Podoliae, Ilustrissimi, Excelentissimi ac Reverendissimi Domini Adami Comitis in Krasne stemmatis Korwin Krasiński Episcopi Camenecensis, equilis Aquilae Albae, ordinaria et delegata Apostolica Sanctissimi Domini Eius Nominis Pii Papae VI aucthoritate, anno salutis 1777-mo, die 11-ma mensis Augusti inchoatae in anno vero sequenti 1778 peractae et finitae"l. Rękopis zawiera akta wizytacji katedry kamienieckiej, jej kapituły oraz kolegium wikariuszy katedralnych. Poza katedrą dotknięty został temat seminarium oraz kościołów kamienieckich. Jest to zatem zasadnicza część wizytacji diecezji kamienieckiej, która obejmuje kościelny Kamieniec z jego kościołem katedralnym pod wezwaniem świętych Apostolów Piotra i Pawła ${ }^{2}$.

Rękopis rozpoczyna list pasterski biskupa kamienieckiego Adama Krasińskiego $^{3}$ z 11 sierpnia 1777 r., po którym następuje kwestionariusz zawierający szczegółowe pytania dotyczące cyborium, chrzcielnicy, olejów świętych, relikwii, ołtarzy, kaplic, obrazów, szat i argenterii, opisu kościoła i cmentarza, majątku kościelnego, osoby proboszcza, parafii i parafian, także osób zakonnych, bractw oraz szpitali-przytułków. Odpowiedzi na pytania przygotowane w kwestionariuszu należało sporządzić w dwu egzemplarzach; jeden przesłać do Konsystorza, a drugi zdeponować $w$ archiwum. Wizytacja biskupa Krasińskiego ma więc duże znaczenie dla obrazu Kościoła kamienieckiego na końcu okresu staropolskiego, a zwłaszcza dla kościoła katedralnego w Kamieńcu Podolskim.

Część pierwsza w całości poświęcona kościołowi katedralnemu została zapisana na stronach 39-153. Od strony 39 na dwudziestu kolejnych kartach znajduje się opis kościoła katedralnego. Następnie autor wizytacji opisal krótko zakrystię katedralną (s. 58-59), by przejść do omówienia argenterii najpierw zakrystii kościoła katedralnego (relikwiarze, monstrancje, puszki, kielichy, naczynia na oleje święte, krzyże, trybularze i łódki, tace z nalewkami, lichtarze i lampy), a po-

${ }^{1}$ Archiwum Kapituły Katedralnej na Wawelu, b. sygn.

2 Poza Kamieńcem diecezja kamieniecka była zorganizowana w 6 dekanatów, 58 parafii i kilka filii. Por. S. L i t a k, Kościót laciński w Rzeczypospolitej okolo 1772 roku, Lublin 1996, s. $367-370$.

${ }^{3}$ W. Szczygielski, Krasiński Adam, PSB 15, s. 160-166. 
tem do argenterii ołtarzy wielkiego, św. Anny, św. Jana Nepomucena, św. Michała, św. Judy Tadeusza, św. Maurycego, Świętej Trójcy oraz kaplic Biskupiej i Radzieckiej. Osobno omówiono srebra kościołów parafialnych w Husiatynie i Okopach. Opis argenterii zajmuje strony 60-77. Po nim następuje wykaz drewnianych relikwiarzy „od Ks. Pakoszewskiego archidiakona katedralnego kamienieckiego do tejże katedry sumptem jego sporządzone i darowane". Zbiorek liczy 14 sztuk. Od strony 78 do 86 zapisane zostały ,garnitury, jako to: ornaty, dalmatyki z stułami, manipularzami, palkami, welami, bursami i kapami”. Najpierw omówiono szaty liturgiczne służące członkom kapituly kamienieckiej, a następnie niższego duchowieństwa. Opisy rozpoczynają komplety czyli tzw. apparata, a następnie ornaty, dalmatyki, alby, humerały, gotowalnie, obrusy, korporały, ręczniki ołtarzowe, puryfikaterze, paski, bursy, vela i palki. Z pozostałych sprzętów wspomniano antepedia, a wymieniono krzyże, baldachimy, choragwie, pontyfikalia, księgi, dzwony i dzwonki, lichtarze, sprzęty cynowe, poduszki, umbrakula, lustra, a wreszcie naczynia mosiężne i żelazne. Wykaz kończą „lampy, ampułki i cienie”. Na stronach 97-140 znajduje się opis kaplic i oltarzy w kościele katedralnym. Wizytacja wymienia osiem oltarzy:

Kaplica Figulorum pw. św. Leonarda

Kaplica Ducha Św.

Kaplica Herburtoviana

Kaplica Sartorum pw. św. Marcina

Kaplica św. Sebastiana

Kaplica Stonczeviana

Kaplica Dominorum Consulum Camenecensium

Kaplica Bożego Ciała

Po omówieniu kaplic umieszczono regestr sprzętów kościelnych ołtarza Trójcy Świętej, spisany w 1750 r., a następnie „Deces rzeczy, których nie dostaje do ołtarza Św. Trójcy, podług wizyty J.W. Xiędza Sierakowskiego, Biskupa Kamienieckiego" ". Dalsze miejsca zajmują bractwa przy kościele katedralnym. Wizytacja wymienia ich pięć: Bractwo Literatów, Bractwo Świętej Trójcy, Bractwo Bożego Ciała, Bractwo św. Jana Nepomucena, Bractwo św. Anny.

Pierwszą część wizytacji poświęconą kościołowi katedralnemu kończy opis altarii św. Jana Nepomucena i św. Judy Tadeusza.

D r u g i m znaczącym tematem omawianego rękopisu wizytacji jest kapituła katedralna kamieniecka, obecna na stronach (154-258) Wizytacji. Tę część wizytacji rozpoczyna obszerny dokument królewski Stefana Batorego. Po nim następuje wykaz prałatów i kanoników kapituly kamienieckiej. W 1777 r. kapituła liczyła siedmiu prałatów i piętnastu kanoników gremialnych. Jako pierwsza godność występuje dziekan. Prawo patronatu na dziekanię, kustodię, scholasterię, kantorię i kancelarię posiadal biskup kamieniecki. Prepozyta prezentował kolator de Rychty Humiecciana, a archidiakona wybierała kapituła z dwóch osób proponowanych przez biskupa diecezjalnego.

Kapituła liczyła siedem prałatur, w następującej kolejności: dziekan, prepozyt, archidiakon, kustosz, scholastyk, primiceriusz i kanclerz. Kanonii liczyła

${ }^{4}$ J. A t a ma n, W. H. Sierakowski i jego rzqdy $w$ diecezji przemyskiej, Warszawa 1936, s. 8-10; E. B u rd a, Sierakowski Wactaw Hieronim, PSB 37, s. 307-308. 
piętnaście. Zajmowali je w omawianym czasie następujący kanonicy: Jan Brzeziński, Sebastian Kwolek, Suski, Matuszewski, Jan Białobrzeski, Franciszek Sierakowski, Kościeński, Leszczyński, Wojciech Skarszewski, Piotr Petz, Marcin Radochowski, Jan Wiszniowski, Piotr Malczewski, Xawery Michałowski i Adam Stadnicki ${ }^{5}$. Zwraca uwagę fakt, że od kanonii kamienieckiej rozpoczynał swoja karierę duchowną ks. Wojciech Skarszewski, późniejszy arcybiskup warszawski i prymas Królestwa Polskiego ${ }^{6}$.

Za kanoniami gremialnymi miejsce w stallach kościoła katedralnego zajmowali kanonicy honorowi. Po prezentacji osób kapitulnych autor Wizytacji omawia uposażenie kapituły kamienieckiej. Nie jest ono kompletne.

Po omówieniu uposażenia ze wsi Poczapińce, Beznoskowce, Milowce i Załucze w akcie wizytacji strony 221-227 pozostają niezapisane. Dalsze miejsce zajmuje opis sum kapitałowych.

Po omówieniu składu osobowego i uposażenia zamieszczono zestawienie obligacji członków kapituły, do której dodano porządek odprawianych aniwersarzy w porządku kalendarza, a zaraz po nim prawa i przywileje prałatów i kanoników gremialnych, a także kanoników honorowych.

Trzeci, przedostatni blok materiałów umieszczonych w Wizytacji (s. 258-299) jest mniej czytelny. Znalazły się w nim omówienie kolegium mansjonarzy kościoła katedralnego, a następnie seminarium (s. 264-273). Dalej jest mowa o sumach na wykup niewolników oraz krótkie wyliczenie innych kościołów trzech obrządków w następującym porządku:

Kościoły w obrządku łacińskim

- kościół pojezuicki

- kościół dominikanów pw. św. Mikołaja

- kościół franciszkanów pw. Wniebowzięcia NMP

- kościół karmelitów bosych pw. NMP de Victoria

- kościół trynitarzy

- kościół dominikanek pw. św. Michala Archanioła

Kościoły w obrządku greckim

- kościół katedralny pw. Narodzenia św. Jana Chrzciciela

- kościół pw. św. Piotra i Pawła

- kościół pw. Bożego narodzenia

- kościół pw. św. Mikołaja

- kościól bazylianów pw. Świętej Trójcy

Kościoły w obrządku ormiańskim

- kościól pw. św. Mikołaja

- kościół pw. Zwiastowania Pańskiego

- kościół pw. sw. Grzegorza, patriarchy ormiańskiego

Ten trzeci blok zagadnień kończy decretum reformationis (s. 280-299), a w nim to, co dotyczy kościoła katedralnego, dóbr dziedzicznych kapituły, seminarium, sum na wykup niewolników. Najwięcej miejsca dekret poświęca kapitule i szczegółowym jej statutom, m.in. o optowaniu domów kapitulnych, o rezydencji

${ }^{5}$ Pozycje kapituły kamienieckiej w stosunku do innych kapituł przedstawił ks. B. Kumor $w$ tabeli do pracy pt. Ustrój i organizacja Kościola polskiego w okresie niewoli narodowej 1772-1918, Kraków 1980, s. 305.

${ }^{6}$ M. D e s z c z y ń s k a, E. Z i e 1 i ń s k a, Skarszewski Wojciech, PSB 38, s. 51. 
i prezencji, o tzw. kanoniku ślepym, o kanoniku penitencjarzu, o kapaliach, o używaniu dystynktorium, o aniwersarzach, czy o porządku przeprowadzania kapituł generalnych.

Ostatnia, c zwarta część wizytacji niemal w całości została poświęcona wikariuszom katedralnym. Rozpoczyna ją akapit o prawach i obowiazkach wikariuszy i o domach wikariuszowskich i stanie ich zachowania. Strony 327-336 wypełnia opis kościoła parafialnego w Zińkowcach. Dalej tekst Wizytacji podaje skład kolegium wikariuszy. W 1777 r. przy kościele katedralnym w Kamieńcu było ich pięciu. Byli nimi księża: Antoni Chmielewski, Tomasz Bukowski, Stanisław Pachniewski, Bartłomiej Popiel i Franciszek Pruski.

Końcowe karty rękopisu (s. 337-341) poświęcone zostały takim kwestiom, jak: obowiązki wikariuszy, obowiazki mszalne wikariuszy, utrzymanie wikariuszy, kapituły wikariuszów i parafianie parafii katedralnej. Tę część zamyka zestawienie dochodów wikariuszów i rekapitulacja ich obowiązków. Ostatnim tekstem zamieszczonym w Wizytacji jest dekret reformacyjny Kolegium księży wikariuszów.

Opisany wyżej rękopis wizytacji znajduje się w Archiwum Kapitulnym na Wawelu. Jest ważnym źródłem dla historii katedry kamienieckiej, która za poprzednika biskupa A. Krasińskiego, bo za rządów biskupa Mikołaja Dembowskiego została poddana gruntownej restauracji. Między innymi zyskała nową fasadę i wiele elementów wystroju wewnętrznego. Symbolem tej restauracji stała się figura Matki Bożej ustawiona w 1756 r. na minarecie przed katedrą?. Rękopis wizytacji trafił do zbioru kapitulnego zapewne w części spuścizny po ks. arcybiskupie F. Symonie. W ten sposób stare, wawelskie Archiwum Kapitulne strzeże zapisanej cząstki dziejów Kościoła kamienieckiego, a przez tę publikację chce o nim przypomnieć historykom zajmującym się dziejami Kamieńca Podolskiego ${ }^{8}$.

Jest ostatnią w szeregu wizytacji diecezji kamienieckiej XVII i XVIII w. ${ }^{9}$

\section{Manuscript of Inspection of Kamieniecka Diocese in 1777 in Archives of Cracow Cathedral Chapter at Wawel Summary}

In the capitulary archives at Wawel a manuscript is kept of the inspection of the Kamieniecka diocese dating from 1777, which was ordered by bishop Adam Krasiński. The

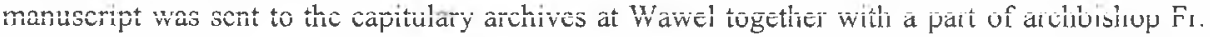
Symon's legacy. The article discusses the inspection manuscript, which was the last inspection in the Kamieniecka diocese in the Old Polish period.

${ }^{7}$ W. Konopczyński, Dembowski Mikolaj, PSB 5, s. 97; A. Rasszczupk in, Katedra św. Apostotów Piotra i Pawła w Kamieńcu Podolskim. Przewodnik wydany w roku 2003 , s. 8 .

${ }^{8}$ Miejsce jego przechowywania notuje S. Litak w cytowanej już pracy pt. Kościól laciński..., s. 367 .

9 J. M u cha, Organizacja diecezji kamienieckiej do r. 1795, „Roczniki Teologiczno-Kanoniczne" t. 30, z. 4, 1983, s. 108. 